\title{
Application of passive capillary samplers in water stable isotope investigations of snowmelt - A case study from Slovenia
}

\author{
Polona Vreča ${ }^{*}$, Mihael Brenčič ${ }^{2,3}$, Anja Torkar ${ }^{2}$ \\ ${ }^{1}$ Jožef Stefan Institute, Department of Environmental Sciences, Ljubljana, Slovenia. E-mail: polona.vreca@ijs.si \\ 2 Department of geology, Faculty of Natural Sciences and Engineering, University of Ljubljana, Ljubljana, Slovenia. \\ E-mails: mihael.brencic@geo.ntf.uni-lj.si, anja.torkar@geo.ntf.uni-lj.si \\ ${ }^{3}$ Geological Survey of Slovenia, Ljubljana, Slovenia. \\ * Corresponding author. Tel.: +386 15885304. Fax: +386 15885346. E-mail: polona.vreca@ijs.si
}

\begin{abstract}
In this paper we describe the use of modified passive capillary samplers (PCSs) to investigate the water isotope variability of snowmelt at selected sites in Slovenia during winter 2011/2012 and during winter 2012/2013. First, PCS with 3 fibreglass wicks covering approximately $1 \mathrm{~m}^{2}$ were tested to determine sample variability. We observed high variability in the amount of snowmelt water collected by individual wick (185 to $345 \mathrm{~g}$ ) and in the isotope composition of oxygen $\left(\delta^{18} \mathrm{O}-10.43 \%\right.$ to $-9.02 \%$ ) and hydrogen $\left(\delta^{2} \mathrm{H}-70.5 \%\right.$ to $-63.6 \%$ of of the collected water. Following the initial tests, a more detailed investigation was performed in winter 2012/2013 and the variability of snowmelt on the local scale among the different levels (i.e. within group, between the close and more distant groups of wicks) was investigated by applying 30 fibreglass wicks making use of Analysis Of Variance (ANOVA) and a balanced hierarchical sampling design. The amount of snowmelt water collected by an individual wick during the whole experiment was between 116 and $1705 \mathrm{~g}$, while the isotope composition varied from $-16.32 \%$ to $-12.86 \%$ for $\delta^{18} \mathrm{O}$ and from $-120.2 \%$ to $-82.5 \%$ for $\delta^{2} \mathrm{H}$. The main source of variance $(80 \%)$ stems from the variability within the group of wicks (e.g. within group) while other sources contribute less than $20 \%$ of the variability. Amount weighted samples for the 2012-2013 season show no significant differences among groups, but significant differences for particular sampling events were observed. These investigations show that due to the variability within the group of wicks, a large number of wicks $(>5)$ are needed to sample snowmelt.
\end{abstract}

Keywords: Snowmelt; Passive capillary sampler; Oxygen and hydrogen isotopes; Balanced hierarchical sampling design; ANOVA; Slovenia.

\section{INTRODUCTION}

Snow and snowmelt significantly contribute to river discharge and groundwater recharge (Bavay et al., 2013; DeWalle and Rango, 2008). The role of mountains in providing the indispensable water resources for municipal and industrial water supply, irrigation, hydropower production and other environmental services is well known and unquestioned (Fayad et al., 2017; Mankin et al., 2015). In Europe in particular, the Alps, with their seemingly vast water resources, are of immeasurable importance for the economic and cultural development of not only the Alpine Arc, but also the lowlands and major urban areas far beyond (Viviroli and Weingartner, 2004; Viviroli et al., 2011). In the Alpine climate zone, the amount of water stored in the snowpack and the amount released during snowmelt varies considerably in space and time and substantially influences the water cycle and aquifers recharge during the snowmelt period (Weber et al., 2016). Therefore, an accurate snow balance study is necessary in mountain areas for determining water storage capacity and for assessing water residence times, which are crucial for protecting alpine water resources. Recent climate warming and changes in atmospheric circulation patterns have resulted in reductions in the duration of the snow cover season, the amount of water stored in the snowpack, and a trend towards an earlier melt (Hohenwallner et al., 2011). Therefore, monitoring the effects of climate change on water resources requires techniques capable of identifying and quantifying the relative contribution of snowmelt to surface water flow and groundwater recharge (Penna et al., 2014).
Isotopes of oxygen and hydrogen in water molecule proved to be useful tracers of water cycle and have played an important role in hydrology in investigating of snow and its influence on runoff (e.g. Engel et al., 2016; Friedman et al., 1991; Jeelani et al., 2017; Moser and Stichler, 1974; Sokratov and Golubev, 2009). A major challenge when using these methods is identifying the contribution of snowmelt to runoff and determining the appropriate isotope composition of the snowmelt (Lee et al., 2010; Penna et al., 2014), which is variable at the local and regional scale (DeWalle and Rango, 2008; Pomeroy and Brun, 2001). Historically, different approaches were adopted like investigating snow cores, using snowmelt lysimeters or in-situ sampling of snowmelt (Penna et al., 2014 and references therein). Recently, in the frame of the project "Use of environmental isotopes in assessing water resources in snow glacier and permafrost dominated areas under changing climatic conditions" managed by the International Atomic Energy Agency (IAEA), passive capillary samplers (PCS) based on a modified design by Frisbee at al. (2010), were placed at 11 sites in ten partner countries (Penna et al., 2014). A novel approach for obtaining snowmelt water samples for isotope analysis was presented including the strengths and weaknesses of proposed PCS method in comparison to other techniques. In each participating country, the PCSs were deployed according to its own specific research questions and requirements (Jeelani et al., 2016; Krajči et al., 2016; Massone et al., 2016; N'da et al., 2016; Penna et al., 2014, 2017).

In Slovenia, previous isotope investigations (Brenčič and Vreča, 2016; Ogrinc et al., 2008; Ortar et al., 2013; Torkar, 2016; Torkar et al., 2016; Vreča et al., 2013) revealed large 
seasonal variations in the isotope composition of hydrogen and oxygen in precipitation, surface waters, groundwater and the snowpack. The influence of snowmelt, although known to be an important driver of these isotopic fluctuations, was not quantified. Information on snowmelt isotope composition is important for estimating recharge components, residence times and the recharge area. To obtain this information it is important to investigate the variability of the snowmelt in time and space.

The aim of the present paper is to present in detail the results of testing modified PCSs and the evaluation of the stable isotope composition of snowmelt based on a balanced Analysis of Variance where sources of variance at different levels (at the temporal and spatial scales) were predefined.

\section{MATERIALS AND METHODS Study area}

PCSs were positioned on the flat plain above the resurgence area of the River Radovna. The Radovna valley is situated in north-west Slovenia in the eastern Julian Alps (Figure 1). It lies between the two high karstic plateaus of Pokljuka and Mežakla. Both plateaus together along with the eastern part of the Julian Alps represent the Radovna River watershed. The bottom of the valley is filled with fluvioglacial and alluvial sediments creating a large unconfined porous aquifer used as drinking water supply for 29,700 inhabitants. A detailed description of the River Radovna valley and of the study site can be found in Torkar et al. (2016).

The wider area of the Julian Alps is characterised by high precipitation, rapid runoff, and low evaporation (Dolinar et al., 2008; Frantar et al., 2008). Its climate is defined by long cold winters and short summers with frequent precipitation. In the upper Radovna River valley a meteorological station is located at Zgornja Radovna (ZR, Figure 1; 46 $25^{\prime} 41.88^{\prime}, \mathrm{N}$, $13^{\circ} 56^{\prime} 36.24^{\prime \prime}$ E, altitude $750 \mathrm{~m}$ a.s.1.) where precipitation and snow depth are measured daily (Nadbath, 2012). Snow starts to accumulate in late autumn. The snow cover is regular and typically lasts for more than 100 days. In the spring/summertime, snowmelt feeds the streams (Torkar et al., 2016). In recent years, the snow cover season has become shorter and the average snow depth has reduced, which has affected the discharge regime (Dolinar et al., 2008; Frantar et al., 2008).

Our investigations were performed during winter 2011/2012 and winter 2012/2013. The maximum snow depth at station ZR was only $18 \mathrm{~cm}$ in winter $2011 / 2012$ and $109 \mathrm{~cm}$ in winter $2012 / 2013$. In winter $2011 / 2012$ the first appearance of snow was in the middle October followed by two periods with snow cover, one from the middle of December (17.12.2011) to the beginning of January (10.1.2012) and one at the beginning of February (4.2.2012) where snow remained on the ground until the end of February (28.2.2012). In winter 2012/2013, the first appearance of snow was at the end of October and then again in the beginning of December (1.12.2012) lasting until the beginning of January (4.1.2013) and then again from the middle of January (14.1.2013) until the end of April 2013 (20.4.2013) (ARSO, 2017).

\section{Sampling}

Modified PCSs as described in Penna et al. (2014) were used for the first time in winter 2011/2012 in six different countries. We performed the first tests at the meteorological station ZR (Figure 1). We used one PCS constructed from a plastic box with 3 fibreglass wicks (IAEA) passing through the lid of a sample collection bottle (1L) with the fiddleheads placed direct- ly on the ground. The whole PCS covered an area of $1 \mathrm{~m}^{2}$ and was installed on 26 November 2011. The snowmelt samples were collected on 10 May 2012.

Based on the results from winter 2011/2012 we performed more extensive investigations in winter 2012/2013 to determine the variability of snowmelt isotope composition associated with the PCS at the local and regional scales (Penna et al., 2014). Variance component analysis based on an Analysis Of Variance (ANOVA) and a balanced hierarchical sampling design (Figure 2) was used to identify different possible sources of variability of amount of collected water and its stable isotope composition to compare: 1) wicks inside of a group (level A - defined as within group variability); 2) groups of wicks that are close to each other (level B - defined as variability between sampling clusters); 3) variability in the wider space (level C - defined as variability between sampling locations) on plain where level B samplers are separated for several hundred meters at the same altitude. The area selected for installation of the PCS was considered as homogenous with no significant differences in climate and morphology.

PCSs were prepared according to a common protocol (IAEA) including construction and installation (Penna et al, 2014). The most important part of the PCS is the wick (a fiberglass rope with a core, $10 \mathrm{~mm}$, No. 1677 995, Bergal Erfurter Flechttechnik GmbH). The PCSs for our experiment were prepared in the laboratory as follows:

1. The rope (wick) was washed with deionized water until the measured electrical conductivity reached $<100 \mu \mathrm{S} / \mathrm{cm}$.

2. The wick was then dried and cut into $80 \mathrm{~cm}$ sections.

3. Plastic tubing was cut into $60 \mathrm{~cm}$ sections and the wick was pulled through the plastic tubing allowing $20 \mathrm{~cm}$ of the wick to remain exposed. The exposed wick was then rolled and secured with plastic band.

4. The wick was then fed through lid of a sample collection $1 \mathrm{~L}$ bottle. The final PCS consisted of a box with 5 wicks connected to bottles (Penna et al., 2014).

5. Finally, the exposed wicks were placed on the top of a plastic barrier and secured to the ground using a u-shaped pin (Penna et al., 2014).

We installed the PCSs at 2 locations in the Radovna River valley near to the precipitation station ZR (Figure 1) approximately $250 \mathrm{~m}$ apart at an altitude of $740 \mathrm{~m}$ a.s.1. The locations were as follows:

$$
\begin{aligned}
& \text { - Gogala - G }\left(46^{\circ} 25^{\prime} 50.14^{\prime}{ }^{\prime} \mathrm{N}, 13^{\circ} 57^{\prime} 2.18^{\prime \prime} \mathrm{E}\right) \\
& \text { - Guhar - Gu }\left(46^{\circ} 25^{\prime} 47.21^{\prime}{ }^{\prime} \mathrm{N}, 13^{\circ} 56^{\prime} 51.58^{\prime} \mathrm{E}\right)
\end{aligned}
$$

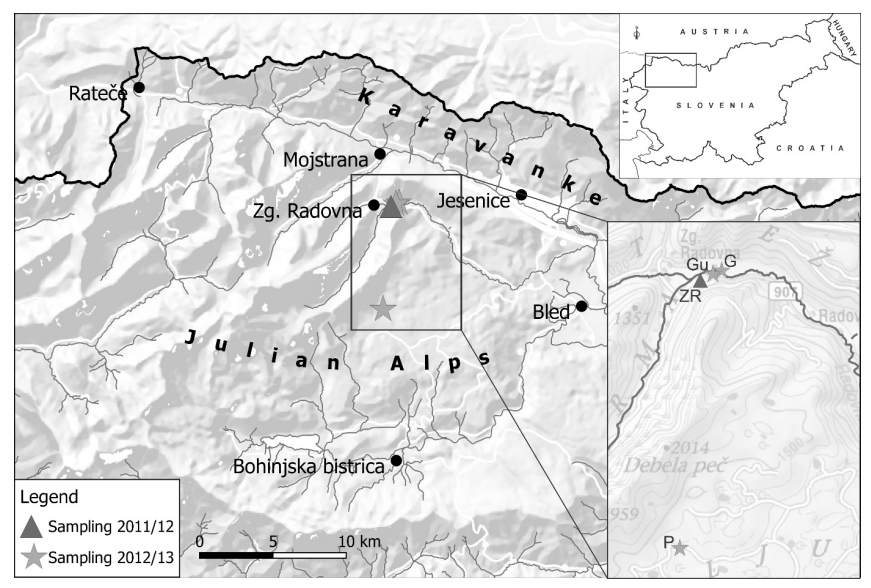

Fig. 1. Relief map showing sampling locations: ZR - Zgornja Radovna, G - Gogala, Gu - Guhar and P - Pokljuka. 


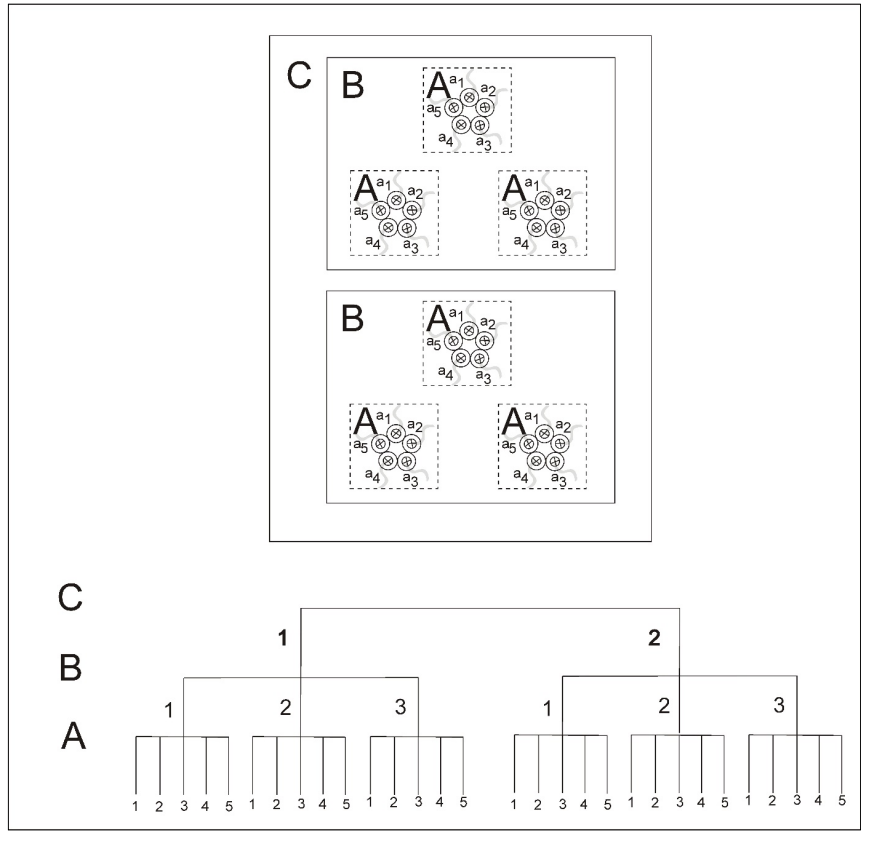

Fig. 2. Sampling design for PCS snowmelt investigations at $\mathrm{G}$ and Gu in winter 2012/2013.

At each location a cluster of 3 PCS boxes each with 5 wicks were installed (4 December 2012) according to sampling design shown in Figure 2. We collected the samples at $\mathrm{G}$ and $\mathrm{Gu}$ twice during winter 2012/2013, i.e. at the end of 2012 (location G) and beginning of 2013 (location $(\mathrm{Gu})$ and at the end of the snow season in April 2013. The samples were transported back to the laboratory where the amount of sample (expressed in $\mathrm{g}$ ) was recorded and stored in $30 \mathrm{~mL}$ high-density polyethylene (HDPE) bottles prior to isotope analysis.

To assess the variability at the different altitudes we installed a PCS with 5 wicks in the recharge area of the Radovna River on the Pokljuka plateau (location P; 46 $21^{\prime} 54.80^{\prime \prime} \mathrm{N}$, $13^{\circ} 56^{\prime} 15.50^{\prime \prime}$ E, $1330 \mathrm{~m}$ a.s.1., Figure 1), south of the Radovna sampling site on the 1.12.2012. The sampler was emptied only at the end of the snow season (18 May 2013). Due to high snow cover in winter 2012/2013 not all of the snowmelt water was collected at location $\mathrm{P}$ (maximum $1115 \mathrm{~g}$ ) and as a result the data were used only for a qualitative comparison and were not included in the ANOVA.

\section{Isotope analysis}

The oxygen stable isotope composition $\left(\delta^{18} \mathrm{O}\right.$ in \%o) of three samples collected in 2012 was determined using isotope ratio mass spectrometry (IRMS). For these samples we used a IsoPrime MultiFlow-Bio module while all of the other samples were analysed using a Varian MAT 250 IRMS at the Jožef Stefan Institute (JSI) by means of water- $\mathrm{CO}_{2}$ equilibration technique. All measurements were carried out against laboratory standards periodically calibrated against primary IAEA calibration standards to VSMOW/SLAP scale. Long-term measurement precision of control sample was better than 0.07 $\%$. Hydrogen $\left(\delta^{2} \mathrm{H}\right.$ in \%o $)$ was determined in the Isotope Hydrology Laboratory (IHL) at the IAEA by means of off-axis integrated cavity output laser spectroscopy (OA-ICOS, Los Gatos Research, Mountain View CA, United States of America). All measurements were carried out against laboratory standards calibrated against primary IAEA calibration standards to VSMOW/SLAP scale. The typical uncertainty reported as the long-term standard-deviation of a control sample was $0.5 \%$ for $\delta^{2} \mathrm{H}$.

\section{Data evaluation}

Basic descriptive statistics, i.e. weighted mean, minimum, maximum and range and the deuterium excess $\left(d=\delta^{2} \mathrm{H}-\right.$ $8 \times \delta^{18} \mathrm{O}$; Dansgaard, 1964) were calculated for each PCS. These statistics are illustrated as box-plots (i.e. $\min -\max$, first and third quartiles, median and mean). The weighted mean was calculated for data from $\mathrm{G}$ and $\mathrm{Gu}$ since the bottles were emptied twice during the winter 2012/2013 and consequently isotope composition of water for the first and second sampling period was measured separately. The mean $\delta^{18} \mathrm{O}, \delta^{2} \mathrm{H}$ and $d$ values weighted according to the amount of water were calculated based on two sampling events for the whole sampling period.

Samples were collected based on a balanced sampling design (Figure 2). Such a design enables the evaluation of the results using ANOVA - two way crossed classification interaction model with the balanced data for the random model. The first level $\mathrm{C}$, defines the different sampling locations where sampling clusters were separated by more than $250 \mathrm{~m}$; the second level B relates to sampling clusters at each location separated by a few meters, while the third level A is defined as within groups interaction and is observed for variability within an area of approximately $1 \mathrm{~m}^{2}$. Variance components estimations are solved for the variance components based on a linear model. The model of variance components can be defined as: $s_{\text {TOT }}^{2}=s_{A}^{2}+s^{2}{ }_{\mathrm{B}}+s_{\text {INT }}^{2}+s^{2}$. Where $s_{\text {TOT }}^{2}$ is the estimated total variance, $s_{\text {INT }}^{2}$ is the estimated interaction variance and $s^{2}$ is the estimated variance of each variance component A, B, C. All calculations were performed using Microsoft ${ }^{\circledR}$ Excel for Mac Version 15.123. ANOVA and variance component analysis were performed for each sampling campaign and for the whole amount of water weighted mean data set. Readers interested in theoretical details of the variance component analysis should consult Searle et al. (2006).

\section{RESULTS AND DISCUSSION}

During the first snowmelt investigations in winter 2011/2012 we collected only 3 samples (ZR1-1, ZR1-2 and ZR1-3; Table 1). The amount of the collected water varied from 185 to $345 \mathrm{~g}$ (mean $248 \mathrm{~g}$, range $160 \mathrm{~g}$ ) and was smaller than expected in an average winter but reasonable due to particular climatic characteristics during winter 2011/2012 when the ground was mostly uncovered by snow and the maximum snow depth at location ZR was only $18 \mathrm{~cm}$. The $\delta^{8} \mathrm{O}, \delta^{8} \mathrm{H}$ and $d$ values varied between -10.43 and $-9.02 \%$ (weighted mean $-9.96 \%$, range $1.41 \%$ ),-70.5 and $-63.6 \%$ (weighted mean $-68.0 \%$, range $6.9 \%$ ), and 8.5 to $13.1 \%$ o (weighted mean $11.7 \%$, range $4.6 \%$ ), respectively. The data obtained showed high variability in the amount of the collected water and its isotope composition inside of a group of wicks $\left(1 \mathrm{~m}^{2}\right)$.

During winter 2012/2013 we performed sampling according to the balanced design (Figure 2). Results for all 35 wicks installed at $\mathrm{G}, \mathrm{Gu}$ and $\mathrm{P}$ are summarized in Tables 1 to 3 while the descriptive statistics are presented in Table 4. Results for G and $\mathrm{Gu}$ are presented in Tables 2 and 3 while weighted means for each wick are included in Table 1. Similarly as for winter 2011/2012, we observed considerable variation in the amount of collected water and its isotope composition at all locations and also between the two sampling campaigns at $\mathrm{G}$ and $\mathrm{Gu}$ (Table 4, Figures 3-5). In addition, we observed at both locations a large variability in the amount of water collected 
Application of passive capillary samplers in water stable isotope investigations of snowmelt - A case study from Slovenia

Table 1. Amount of collected water (Amount), isotope composition of oxygen $\left(\delta^{8} \mathrm{O}\right)$ and hydrogen $\left(\delta^{2} \mathrm{H}\right)$ and deuterium excess $(d)$ for all wicks installed at ZR, G, Gu and P.

\begin{tabular}{|c|c|c|c|c|c|c|}
\hline Wick label & Sampling $p$ & & Amount [g] & $\delta^{18} \mathrm{O}[\% 0]$ & $\delta^{2} \mathrm{H}[\% \mathrm{o}]$ & $d[\% 0]$ \\
\hline ZR1-1 & 26.11 .2011 & 10.5 .2012 & 185 & -10.17 & -68.3 & 13.1 \\
\hline ZR1-2 & 26.11 .2011 & 10.5 .2012 & 345 & -10.43 & -70.6 & 13.0 \\
\hline ZR1-3 & 26.11 .2011 & 10.5 .2012 & 215 & -9.02 & -63.7 & 8.6 \\
\hline G1-1 & 4.12 .2012 & 23.4 .2013 & 1140 & -14.76 & -107.8 & 10.3 \\
\hline G1-2 & 4.12 .2012 & 23.4 .2013 & 463 & -14.19 & -97.6 & 16.0 \\
\hline G1-3 & 4.12 .2012 & 23.4 .2013 & 430 & -15.56 & -111.9 & 12.6 \\
\hline G1-4 & 4.12 .2012 & 23.4 .2013 & 1705 & -14.84 & -103.4 & 15.4 \\
\hline G1-5 & 4.12 .2012 & 23.4 .2013 & 216 & -15.55 & -112.7 & 11.8 \\
\hline G2-1 & 4.12 .2012 & 23.4 .2013 & 645 & -13.49 & -95.0 & 13.0 \\
\hline $\mathrm{G} 2-2$ & 4.12 .2012 & 23.4 .2013 & 727 & -14.33 & -100.7 & 14.0 \\
\hline $\mathrm{G} 2-3$ & 4.12 .2012 & 23.4 .2013 & 703 & -13.71 & -91.5 & 18.2 \\
\hline $\mathrm{G} 2-4$ & 4.12 .2012 & 23.4 .2013 & 1361 & -13.66 & -95.0 & 14.3 \\
\hline $\mathrm{G} 2-5$ & 4.12 .2012 & 23.4 .2013 & 828 & -15.09 & -108.7 & 12.1 \\
\hline G3-1 & 4.12 .2012 & 23.4 .2013 & 1500 & -13.64 & -95.3 & 13.8 \\
\hline G3-2 & 4.12 .2012 & 23.4 .2013 & 259 & -14.39 & -103.3 & 11.8 \\
\hline G3-3 & 4.12 .2012 & 23.4 .2013 & 1385 & -14.55 & -103.5 & 13.0 \\
\hline G3-4 & 4.12 .2012 & 23.4 .2013 & 1236 & -14.94 & -107.7 & 11.9 \\
\hline G3-5 & 4.12 .2012 & 23.4 .2013 & 291 & -14.48 & -106.6 & 9.3 \\
\hline Gu1-1 & 4.12 .2012 & 23.4 .2013 & 880 & -14.06 & -100.7 & 11.8 \\
\hline Gu1-2 & 4.12 .2012 & 23.4 .2013 & 1184 & -14.18 & -102.2 & 11.3 \\
\hline Gu1-3 & 4.12 .2012 & 23.4 .2013 & 1558 & -14.19 & -100.9 & 12.7 \\
\hline Gu1-4 & 4.12 .2012 & 23.4 .2013 & 116 & -16.28 & -120.3 & 10.0 \\
\hline Gu1-5 & 4.12 .2012 & 23.4 .2013 & 1351 & -14.46 & -106.2 & 9.6 \\
\hline Gu2-1 & 4.12 .2012 & 23.4 .2013 & 652 & -14.24 & -103.9 & 10.0 \\
\hline Gu2-2 & 4.12 .2012 & 23.4 .2013 & 247 & -14.72 & -105.3 & 12.5 \\
\hline Gu2-3 & 4.12 .2012 & 23.4 .2013 & 656 & -14.34 & -104.4 & 10.4 \\
\hline Gu2-4 & 4.12 .2012 & 23.4 .2013 & 847 & -14.00 & -103.5 & 8.6 \\
\hline Gu2-5 & 4.12 .2012 & 23.4 .2013 & 507 & -12.86 & -82.5 & 20.4 \\
\hline Gu3-1 & 4.12 .2012 & 23.4 .2013 & 1216 & -15.14 & -108.8 & 12.4 \\
\hline Gu3-2 & 4.12 .2012 & 23.4 .2013 & 985 & -14.47 & -104.4 & 11.4 \\
\hline Gu3-3 & 4.12 .2012 & 23.4 .2013 & 1477 & -14.03 & -99.5 & 12.7 \\
\hline Gu3-4 & 4.12 .2012 & 23.4 .2013 & 746 & -12.94 & -92.4 & 11.1 \\
\hline Gu3-5 & 4.12 .2012 & 23.4 .2013 & 1461 & -13.79 & -97.8 & 12.5 \\
\hline P1-1 & 1.122012 & 18.5 .2013 & 1100 & -14.84 & -106.1 & 12.7 \\
\hline P1-2 & 1.122012 & 18.5 .2013 & 465 & -13.95 & -96.7 & 14.9 \\
\hline P1-3 & 1.122012 & 18.5 .2013 & 215 & -16.32 & -117.0 & 13.7 \\
\hline P1-4 & 1.122012 & 18.5 .2013 & 1100 & -14.51 & -102.7 & 13.5 \\
\hline P1-5 & 1.122012 & 18.5 .2013 & 830 & -14.51 & -102.0 & 14.2 \\
\hline
\end{tabular}
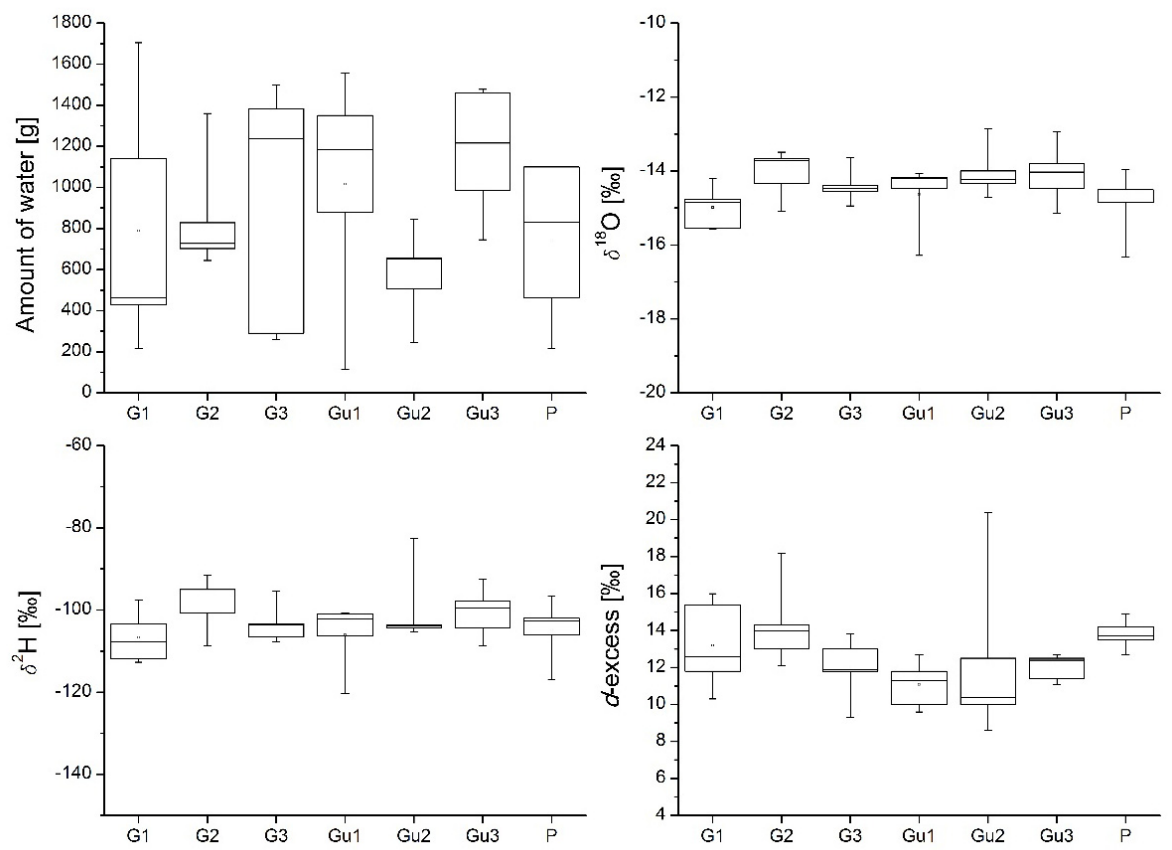

Fig. 3. Box plots of snowmelt and its isotopic composition collected using seven PCSs instaled at G, Gu and P. Sampling period at G and Gu was between 4 December 2012 and 23 April 2013, and at P between 1 December 2012 and 18 May 2013. 

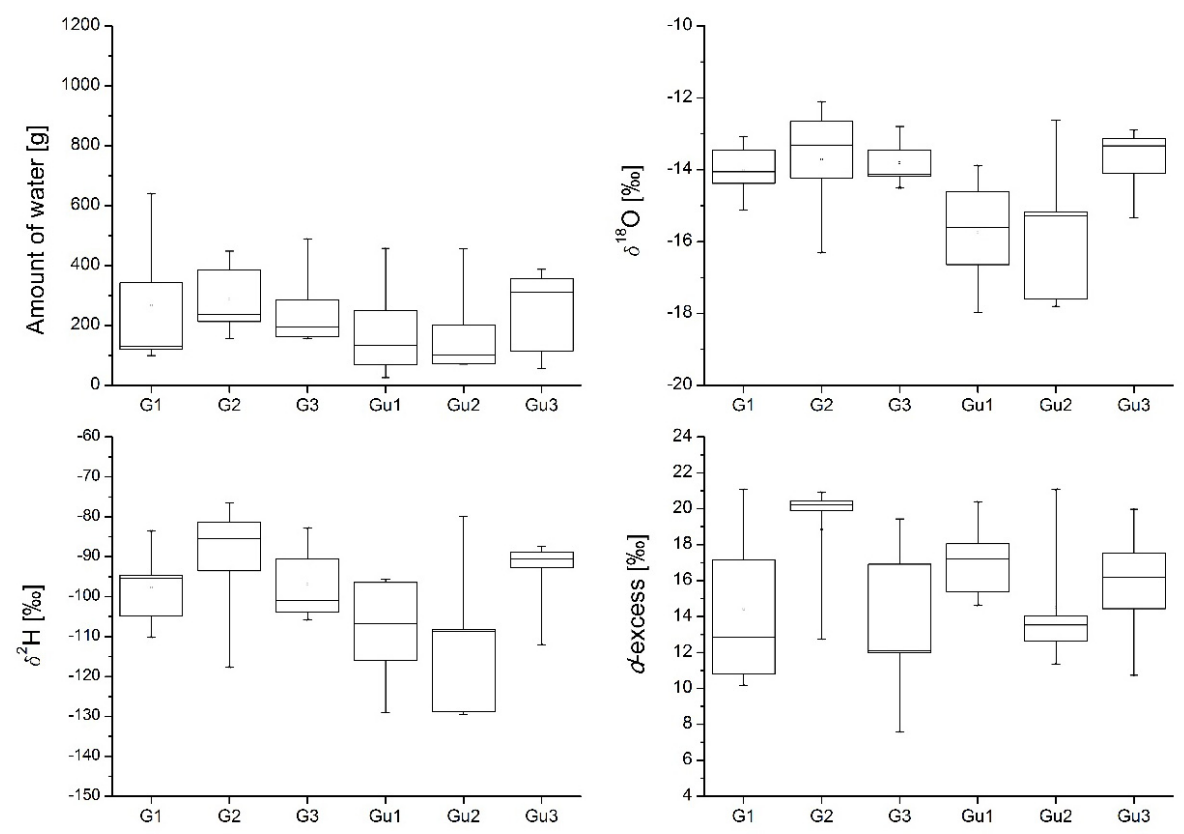

Fig. 4. Box plots of snowmelt and its isotopic composition collected during the first sampling in winter 2012/2013 using 6 PCSs instaled at G and Gu. Sampling period at G was between 4 December 2012 and 27 December 2012 and at Gu between 4 December 2012 and 12 January 2013.
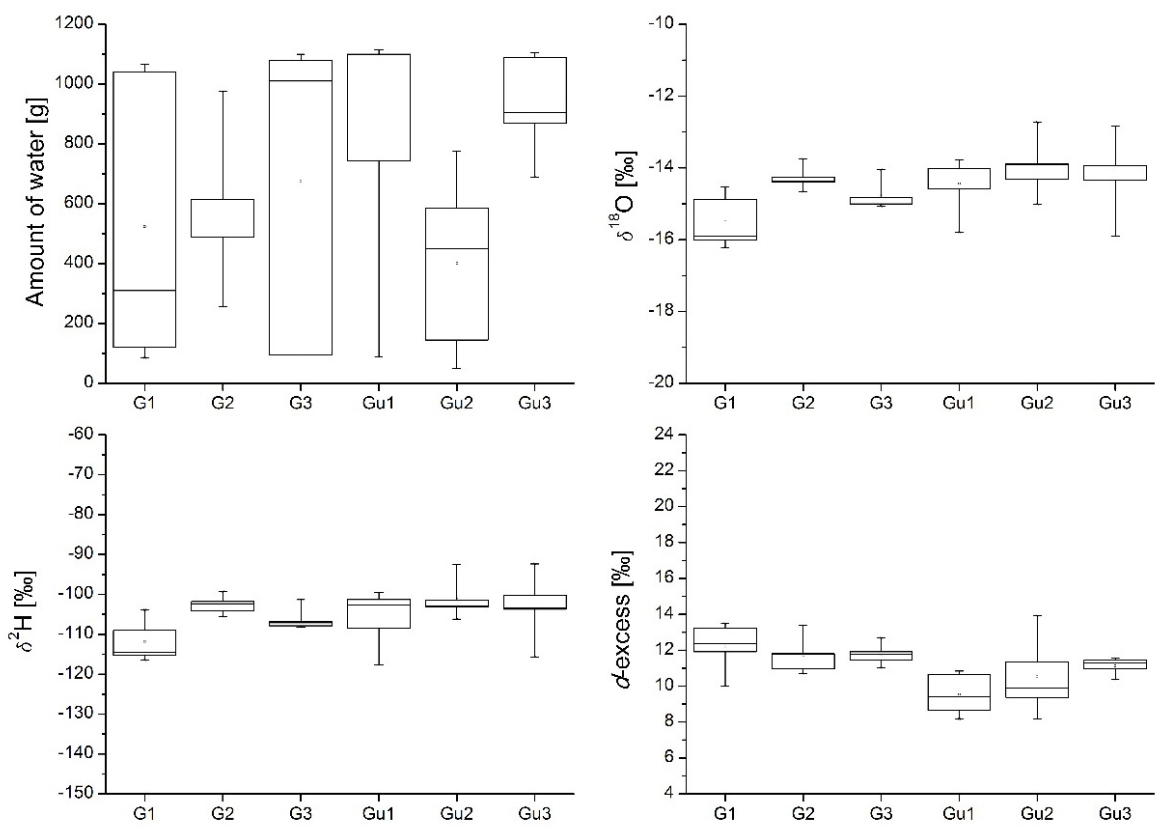

Fig. 5. Box plots of snowmelt and its isotopic composition collected during the second sampling in winter 2012/2013 using 6 PCSs instaled at G and Gu. The sampling period at G was between 27 December 2012 and 23 April 2013 and at Gu between 12 January 2013 and 23 April 2013.

and a small variability in the $\delta^{18} \mathrm{O}, \delta^{2} \mathrm{H}$ and $d$ values (Table 4) during the second sampling period. At $\mathrm{P}$, we collected on average less snowmelt water than at $\mathrm{G}$ and $\mathrm{Gu}$ (Table 4). As expected, the water was depleted in heavier isotopes $\left({ }^{18} \mathrm{O}\right.$ and $\left.{ }^{2} \mathrm{H}\right)$ due to the higher altitude of $\mathrm{P}$.

Results of ANOVA and variance component analysis are presented in Tables 5 and 6 . In all cases, the estimated interaction was not significant at the $\alpha=0.05$ level. It also follows that the mean square for the interaction is smaller than the mean square error of the model meaning that the variance of interaction is less than zero. We interpret it as that sampling at one location does not influence the data obtained from other sampling locations. Accordingly, such variance does not exist and consequently no statistical interaction is present. This conclusion agrees with the selected design and conditions in the field. If we did observe an interaction, another, more complicated model of ANOVA with no interaction would have to be applied.

When performing ANOVA on the data from $\mathrm{G}$ and $\mathrm{Gu}$ during both sampling campaigns the situation appears more complicated. For instance, for amount of water, we observe no significant differences in the mean amount of water sampled, while for $\delta^{18} \mathrm{O}$ the differences are significant between the dif- 
Application of passive capillary samplers in water stable isotope investigations of snowmelt - A case study from Slovenia

ferent sampling locations. We also observe a significant difference between locations in the second sampling period for $d$-excess. For the second observation period, significant differences in averages can be observed between clusters for $\delta^{2} \mathrm{H}$.
From the variance component analysis it follows that the largest part of the variability is present at level A - within groups, inside of the PCS clusters (Tables 5 and 6). The variability at level $\mathrm{A}$ in amount of water is similar as in the case of

Table 2. Amount of collected water (Amount), isotope composition of oxygen $\left(\delta^{18} \mathrm{O}\right)$ and hydrogen $\left(\delta^{2} \mathrm{H}\right)$ and deuterium exces $(d)$ for all wicks installed at $\mathrm{G}$, first and second sampling campaigns.

\begin{tabular}{|c|c|c|c|c|c|c|}
\hline Wick label & Sampling period (f & & Amount [g] & $\delta^{18} \mathrm{O}[\% 0]$ & $\delta^{2} \mathrm{H}[\% 0]$ & $d[\% 0]$ \\
\hline G1-1 & 4.12 .2012 & 27.12 .2012 & 100 & -13.44 & -94.7 & 12.9 \\
\hline G1-2 & 4.12 .2012 & 27.12 .2012 & 343 & -14.06 & -95.3 & 17.2 \\
\hline G1-3 & 4.12 .2012 & 27.12 .2012 & 120 & -14.38 & -104.9 & 10.2 \\
\hline G1-4 & 4.12 .2012 & 27.12 .2012 & 640 & -13.08 & -83.5 & 21.1 \\
\hline G1-5 & 4.12 .2012 & 27.12 .2012 & 131 & -15.12 & -110.2 & 10.8 \\
\hline G2-1 & 4.12 .2012 & 27.12 .2012 & 155 & -12.65 & -81.3 & 19.9 \\
\hline G2-2 & 4.12 .2012 & 27.12 .2012 & 237 & -14.22 & -93.5 & 20.2 \\
\hline $\mathrm{G} 2-3$ & 4.12 .2012 & 27.12 .2012 & 448 & -13.31 & -85.6 & 20.9 \\
\hline $\mathrm{G} 2-4$ & 4.12 .2012 & 27.12 .2012 & 386 & -12.11 & -76.4 & 20.4 \\
\hline $\mathrm{G} 2-5$ & 4.12 .2012 & 27.12 .2012 & 213 & -16.30 & -117.7 & 12.7 \\
\hline G3-1 & 4.12 .2012 & 27.12 .2012 & 490 & -12.79 & -82.9 & 19.4 \\
\hline G3-2 & 4.12 .2012 & 27.12 .2012 & 164 & -14.13 & -101.1 & 12.0 \\
\hline G3-3 & 4.12 .2012 & 27.12 .2012 & 285 & -13.44 & -90.6 & 16.9 \\
\hline G3-4 & 4.12 .2012 & 27.12 .2012 & 156 & -14.50 & -103.9 & 12.1 \\
\hline G3-5 & 4.12 .2012 & 27.12.2012 & 196 & -14.18 & -105.8 & 7.6 \\
\hline G1-1 & 27.12.2012 & 23.4 .2013 & 1040 & -14.88 & -109.0 & 10.0 \\
\hline G1-2 & 27.12.2012 & 23.4 .2013 & 120 & -14.53 & -103.9 & 12.4 \\
\hline G1-3 & 27.12 .2012 & 23.4 .2013 & 310 & -16.01 & -114.6 & 13.5 \\
\hline G1-4 & 27.12.2012 & 23.4 .2013 & 1065 & -15.90 & -115.3 & 11.9 \\
\hline G1-5 & 27.12.2012 & 23.4 .2013 & 85 & -16.21 & -116.5 & 13.2 \\
\hline G2-1 & 27.12.2012 & 23.4 .2013 & 490 & -13.75 & -99.3 & 10.7 \\
\hline G2-2 & 27.12.2012 & 23.4 .2013 & 490 & -14.38 & -104.1 & 11.0 \\
\hline G2-3 & 27.12.2012 & 23.4 .2013 & 255 & -14.40 & -101.8 & 13.4 \\
\hline G2-4 & 27.12 .2012 & 23.4 .2013 & 975 & -14.26 & -102.3 & 11.8 \\
\hline G2-5 & 27.12 .2012 & 23.4 .2013 & 615 & -14.66 & -105.5 & 11.8 \\
\hline G3-1 & 27.12.2012 & 23.4 .2013 & 1010 & -14.04 & -101.3 & 11.0 \\
\hline G3-2 & 27.12 .2012 & 23.4 .2013 & 95 & -14.82 & -107.1 & 11.4 \\
\hline G3-3 & 27.12.2012 & 23.4 .2013 & 1100 & -14.83 & -106.7 & 11.9 \\
\hline G3-4 & 27.12 .2012 & 23.4 .2013 & 1080 & -15.00 & -108.2 & 11.8 \\
\hline G3-5 & 27.12.2012 & 23.4 .2013 & 95 & -15.07 & -107.9 & 12.7 \\
\hline
\end{tabular}

Table 3. Amount of collected water (Amount), isotope composition of oxygen $\left(\delta^{18} \mathrm{O}\right)$ and hydrogen $\left(\delta^{8} \mathrm{H}\right)$ and deuterium exces $(d)$ for all wicks installed at $\mathrm{Gu}$, first and second sampling campaigns.

\begin{tabular}{|c|c|c|c|c|c|c|}
\hline Wick label & \multicolumn{2}{|c|}{ Sampling period (from-to) } & Mass $[\mathrm{g}]$ & $\delta^{8} \mathrm{O}[\% 0]$ & $\delta^{2} \mathrm{H}[\% 0]$ & $d[\%]$ \\
\hline Gu1-1 & 4.12 .2012 & 12.1.2013 & 135 & -15.61 & -106.8 & 18.1 \\
\hline Gu1-2 & 4.12 .2012 & 12.1.2013 & 69 & -16.64 & -115.9 & 17.2 \\
\hline Gul-3 & 4.12 .2012 & 12.1.2013 & 458 & -14.61 & -96.5 & 20.4 \\
\hline Gu1-4 & 4.12 .2012 & 12.1 .2013 & 26 & -17.96 & -129.1 & 14.6 \\
\hline Gu1-5 & 4.12 .2012 & 12.1.2013 & 251 & -13.88 & -95.6 & 15.4 \\
\hline Gu2-1 & 4.12 .2012 & 12.1.2013 & 202 & -17.60 & -129.4 & 11.4 \\
\hline Gu2-2 & 4.12 .2012 & 12.1 .2013 & 102 & -15.28 & -108.2 & 14.1 \\
\hline Gu2-3 & 4.12 .2012 & 12.1.2013 & 71 & -17.80 & -128.9 & 13.5 \\
\hline Gu2-4 & 4.12 .2012 & 12.1.2013 & 72 & -15.18 & -108.8 & 12.7 \\
\hline Gu2-5 & 4.12 .2012 & 12.1 .2013 & 457 & -12.62 & -79.9 & 21.1 \\
\hline Gu3-1 & 4.12 .2012 & 12.1.2013 & 311 & -12.90 & -88.8 & 14.4 \\
\hline Gu3-2 & 4.12 .2012 & 12.1.2013 & 115 & -15.34 & -112.0 & 10.7 \\
\hline Gu3-3 & 4.12 .2012 & 12.1 .2013 & 387 & -13.12 & -87.4 & 17.5 \\
\hline Gu3-4 & 4.12 .2012 & 12.1.2013 & 56 & -14.09 & -92.7 & 20.0 \\
\hline Gu3-5 & 4.12 .2012 & 12.1.2013 & 356 & -13.33 & -90.5 & 16.2 \\
\hline Gu1-1 & 12.1 .2013 & 23.4 .2013 & 745 & -13.77 & -99.5 & 10.7 \\
\hline Gu1-2 & 12.1 .2013 & 23.4 .2013 & 1115 & -14.02 & -101.3 & 10.8 \\
\hline Gu1-3 & 12.1 .2013 & 23.4 .2013 & 1100 & -14.01 & -102.7 & 9.4 \\
\hline Gu1-4 & 12.1 .2013 & 23.4 .2013 & 90 & -15.79 & -117.7 & 8.7 \\
\hline Gu1-5 & 12.1 .2013 & 23.4 .2013 & 1100 & -14.59 & -108.5 & 8.2 \\
\hline Gu2-1 & 12.1 .2013 & 23.4 .2013 & 450 & -12.72 & -92.4 & 9.4 \\
\hline Gu2-2 & 12.1 .2013 & 23.4 .2013 & 145 & -14.31 & -103.1 & 11.4 \\
\hline Gu2-3 & 12.1 .2013 & 23.4 .2013 & 585 & -13.91 & -101.4 & 9.9 \\
\hline Gu2-4 & 12.1 .2013 & 23.4 .2013 & 775 & -13.89 & -103.0 & 8.2 \\
\hline Gu2-5 & 12.1 .2013 & 23.4 .2013 & 50 & -15.01 & -106.2 & 13.9 \\
\hline Gu3-1 & 12.1 .2013 & 23.4 .2013 & 905 & -15.90 & -115.6 & 11.6 \\
\hline Gu3-2 & 12.1.2013 & 23.4 .2013 & 870 & -14.35 & -103.4 & 11.4 \\
\hline Gu3-3 & 12.1 .2013 & 23.4 .2013 & 1090 & -14.34 & -103.7 & 11.0 \\
\hline Gu3-4 & 12.1 .2013 & 23.4 .2013 & 690 & -12.84 & -92.4 & 10.4 \\
\hline Gu3-5 & 12.1.2013 & 23.4 .2013 & 1105 & -13.93 & -100.2 & 11.3 \\
\hline
\end{tabular}


Table 4. Descriptive statistics for amount of collected water (Amount), isotope composition of oxygen $\left(\delta^{8} \mathrm{O}\right)$ and hydrogen $\left(\delta^{2} \mathrm{H}\right)$ and deuterium exces $(d)$ for all wicks installed at G, Gu and P in winter 2012/2013.

\begin{tabular}{|c|c|c|c|c|c|c|c|}
\hline Location & \multicolumn{2}{|c|}{$\begin{array}{l}\text { Sampling period } \\
\text { (from-to) }\end{array}$} & Parameter & Min & $\operatorname{Max}$ & Range & Mean (weighted) \\
\hline \multirow[t]{12}{*}{ G } & \multirow[t]{4}{*}{4.12 .2012} & \multirow[t]{4}{*}{23.4 .2013} & Amount $[\mathrm{g}]$ & 100 & 640 & 540 & 271 \\
\hline & & & $\delta^{18} \mathrm{O}[\% 0]$ & -16.30 & -12.11 & 4.19 & -13.57 \\
\hline & & & $\delta^{2} \mathrm{H}[\% 0]$ & -117.7 & -76.4 & 41.2 & -91.1 \\
\hline & & & $d[\% \mathrm{o}]$ & 7.6 & 21.1 & 13.5 & 17.4 \\
\hline & \multirow[t]{4}{*}{27.12 .2012} & \multirow[t]{4}{*}{23.4 .2013} & Amount $[\mathrm{g}]$ & 85 & 1100 & 1015 & 588 \\
\hline & & & $\delta^{8} \mathrm{O}[\% 0]$ & -16.21 & -13.75 & 2.46 & -14.78 \\
\hline & & & $8^{2} \mathrm{H}[\% 0]$ & -116.5 & -99.3 & 17.2 & -106.7 \\
\hline & & & $d[\% \mathrm{o}]$ & 10.0 & 13.5 & 3.5 & 11.5 \\
\hline & \multirow[t]{4}{*}{4.12 .2012} & \multirow[t]{4}{*}{23.4 .2013} & Amount $[\mathrm{g}]$ & 216 & 1705 & 1489 & 859 \\
\hline & & & $\delta^{18} \mathrm{O}[\% 0]$ & -15.56 & -13.49 & 2.07 & -14.40 \\
\hline & & & $\delta^{2} \mathrm{H}[\% 0]$ & -112.6 & -91.5 & 21.2 & -101.8 \\
\hline & & & $d[\% \mathrm{o}]$ & 9.3 & 18.2 & 8.9 & 13.4 \\
\hline \multirow[t]{12}{*}{$\mathrm{Gu}$} & \multirow[t]{4}{*}{4.12 .2012} & \multirow[t]{4}{*}{12.1 .2013} & Amount $[\mathrm{g}]$ & 26 & 458 & 432 & 205 \\
\hline & & & $\delta^{18} \mathrm{O}[\% 0]$ & -17.96 & -12.62 & 5.34 & -14.19 \\
\hline & & & $\delta^{2} \mathrm{H}[\% 0]$ & -129.4 & -79.9 & 49.6 & -96.6 \\
\hline & & & $d[\% 0]$ & 10.7 & 21.1 & 10.3 & 16.9 \\
\hline & \multirow[t]{4}{*}{12.1 .2013} & \multirow[t]{4}{*}{23.4 .2013} & Amount $[\mathrm{g}]$ & 50 & 1115 & 1065 & 721 \\
\hline & & & $\delta^{8} \mathrm{O}[\% \mathrm{o}]$ & -15.90 & -12.72 & 3.18 & -14.15 \\
\hline & & & $\delta^{2} \mathrm{H}[\% 0]$ & -117.7 & -92.4 & 25.3 & -102.9 \\
\hline & & & $d[\% \mathrm{o}]$ & 8.2 & 13.9 & 5.8 & 10.3 \\
\hline & \multirow[t]{4}{*}{4.12 .2012} & \multirow[t]{4}{*}{23.4 .2013} & Amount [g] & 116 & 1558 & 1442 & 926 \\
\hline & & & $\delta^{18} \mathrm{O}[\% 0]$ & -16.28 & -12.86 & 3.42 & -14.15 \\
\hline & & & $\delta^{2} \mathrm{H}[\% 0]$ & -120.2 & -82.5 & 37.7 & -101.5 \\
\hline & & & $d[\% \mathrm{o}]$ & 8.5 & 20.4 & 11.8 & 11.7 \\
\hline \multirow[t]{4}{*}{$P$} & \multirow[t]{4}{*}{1.12 .2012} & \multirow[t]{4}{*}{18.5 .2013} & Amount $[\mathrm{g}]$ & 215 & 1100 & 885 & 742 \\
\hline & & & $\delta^{18} \mathrm{O}[\% 0]$ & -16.32 & -13.95 & 2.37 & -14.64 \\
\hline & & & $\delta^{2} \mathrm{H}[\% 0]$ & -116.9 & -96.7 & 20.2 & -103.6 \\
\hline & & & $d[\% \mathrm{o}]$ & 12.6 & 14.9 & 2.3 & 13.6 \\
\hline
\end{tabular}

Table 5. Results of the variance component analysis (contributions of components to the total variance are represented in shares expressed by \%) for amount of collected water.

\begin{tabular}{|l|r|r|r|}
\hline Sampling mass & Total sampling & First sampling & Second sampling \\
\hline Between locations & 1.4 & 10.6 & 7.3 \\
\hline Between clusters & 8.0 & 0.3 & 9.6 \\
\hline Within groups & 90.6 & 89.1 & 83.2 \\
\hline
\end{tabular}

Table 6. Results of the variance component analysis (contributions of components to the total variance are represented in shares expressed by $\%$ ) for $\delta^{18} \mathrm{O}, \delta^{2} \mathrm{H}$ and $d$ values.

\begin{tabular}{|l|l|r|r|r|}
\hline Parameter & Level & $\begin{array}{l}\text { Weighted } \\
\text { mean - total } \\
\text { sampling }\end{array}$ & $\begin{array}{l}\text { First } \\
\text { sampling }\end{array}$ & $\begin{array}{l}\text { Second } \\
\text { sampling }\end{array}$ \\
\hline$\delta^{18} \mathrm{O}$ & Between locations & 6.2 & 33.4 & 29.8 \\
\hline & Between clusters & 16.1 & 7.0 & 12.1 \\
\hline & Within groups & 77.6 & 59.7 & 58.0 \\
\hline$\delta^{2} \mathrm{H}$ & Between locations & 0.3 & 24.9 & 18.5 \\
\hline & Between clusters & 14.8 & 3.8 & 16.7 \\
\hline & Within groups & 84.8 & 71.3 & 64.8 \\
\hline$d$ & Between locations & 16.6 & 0.2 & 49.4 \\
\hline & Between clusters & 4.5 & 4.4 & 1.6 \\
\hline & Within groups & 78.9 & 95.4 & 49.0 \\
\hline
\end{tabular}

the total amount. In the case of total amount of collected water, during the first and second sampling campaigns only a small redistribution in the variability source at other two levels appears (Table 5). The variability at level A for $\delta^{8} \mathrm{O}$ and $\delta^{2} \mathrm{H}$ still predominates but is smaller compared to the amount of water weighted means (Table 6). In both cases, a relatively high variability component exists between locations for $\delta^{8} \mathrm{O}$ i.e., $33.4 \%$ and $29.8 \%$ for each sampling campaign, respectively. A similar relation is observed for $\delta^{2} \mathrm{H}$ where this component represents $24.9 \%$ and $18.5 \%$, respectively. According to the significance of differences for $\delta^{8} \mathrm{O}$ it means that at the level of particular sampling campaign they have to be considered. For $d$ values we obtained different results (Table 6) that can be explained by distribution of $d$-excess which is statistically a derived distribution from empirical parent distributions of $\delta^{2} \mathrm{H}$ and $\delta^{18} \mathrm{O}$. Because ANOVA results are not identical for $\delta^{2} \mathrm{H}$ and $\delta^{18} \mathrm{O}$ the $d$ excess for ANOVA is different. For the first sampling campaign nearly all variability is at the level $\mathrm{A}$, but for the second sampling campaign the variation sources are nearly similar for levels $\mathrm{A}$ and $\mathrm{C}$.

The ANOVA for weighted mean isotope composition and cumulative sampling volume shows that between all levels and groups no significant differences in averages are present. In this case variance components reveal how nearly all variability is present for the variance source within groups (Tables 5 and 6), meaning that a large part of the variability is present inside of the sampling cluster of the PCSs. Following the applied model some variability is also present between sampling clusters, but variability between locations is small and can be neglected. The reverse is observed for $d$-excess (Table 6); here variability is relatively large between the sampling sites but negligible between the clusters. A comparison of the results obtained for winter 2012/2013 at P with the results from G and Gu (Table 1) reveals no visual significant difference between the sites (Figure 3 ). The range of variability at $P$ is very similar to other sites.

The differences between the results obtained at $\mathrm{G}$ and $\mathrm{Gu}$ for winter 2012/2013 (Figure 3) and for the two sampling campaigns (Figures 4 and 5) have important implications for interpreting the isotope composition of snowmelt when several snowmelt events are possible during winter such as in the case of Radovna. The data obtained from the first and the second sampling campaigns in winter 2012/2013 at $\mathrm{G}$ and $\mathrm{Gu}$ show differences in variability structure. When we calculate the means weighted by the amount of water, the differences between variability structures representative for particular period diminish and integrate (Tables 5 and 6). This can have important consequences when interpreting residence times in groundwater based on this data. If residence times are short 
(e.g. in karstic aquifers), it is important to observe the isotope composition of each snowmelt event. Contrary, when residence times are long (e.g. in porous aquifers with relatively low permeability), integrated data for all snowmelt events are needed.

Our findings regarding variance component analysis have important implications for the future sampling strategies of snowmelt with PCSs. We have shown that most of the variability is present inside of the PCSs sampling clusters (level A, within groups) and that the share of other variability components is relatively small in homogeneous regions. This shows that the variability in the isotope composition of snowmelt at one location (approx. $1 \mathrm{~m}^{2}$ ) is high and should be sampled using a large number of wicks (more than 5) and at the same time there is no need to sample snowmelt at other places with similar conditions. With a small number of wicks we cannot define the variability in isotope composition. As shown before, the lack of information on isotope composition variability can have important consequences in the case of other models where isotope composition of snowmelt represents input data.

We observed also a large variability in the amount of water collected inside of the PCSs clusters (at level A). This indicates that suction of water by the fiberglass rope and therefore its physical characteristics (permeability and transmissivity) affects the amount of snowmelt water collected in each sampling bottle. Suction of water through the fibreglass wicks also depends on its pre-event state. If the wick is saturated it will behave completely differently than if it is dry. The amount of water collected by the sampler can also be influenced by the fiddlehead position on the ground and how it is exposed on top of the plastic barrier. Similarly, the variance structure between the amount of snowmelt and the stable isotope composition of the snowmelt indicates that it is possible that the amount of collected snowmelt water can influence its isotope composition. Therefore, the physical characteristic of wicks and their influences on the stable isotope composition of snowmelt water must be further investigated.

There are several strengths and weaknesses in applying the PCS method and some of the questions that remain open are already discussed in detail in Penna et al. (2014). During our sampling campaigns we have recorded similar problems. The large variability in the amount of water collected shows that the maximum was somehow limited because some bottles were full or almost full (in our case $34 \%$ of bottles in the second sampling campaign) and therefore we assume that not all the melt water was collected. Similarly, as reported by Penna et al. (2014) there are indications that due to the rapid melting of the snow, not only snowmelt but also the overland flow over still frozen ground was sampled and some rain events were recorded. In addition, snow was already on the ground when we installed the PCS and the samples were not collected immediately after all the snow had melted.

\section{CONCLUSIONS}

In this paper, we present detailed results of snowmelt isotope investigations performed using modified PCS in Slovenia during two winters. The differences were expected in snowmelt isotope composition at different levels due to space and time heterogeneity characteristic for snowpack in temperate areas and related to changes in air temperature, wind, relative humidity and precipitation (snow and rain) events. Testing of the PCS was performed to determine the variability of collected snowmelt water and the stable isotope composition of the samples within a group of wicks distributed over a small area, within sampling clusters at each location separated by a few meters and between locations separated by a few $100 \mathrm{~m}$ but with similar conditions.

Results of applied balanced sampling design and ANOVA revealed no significant differences in the mean values between all levels and groups for amount of water weighted mean values for the entire winter. However, if snow is not permanently present on the ground through the winter and the snowmelt is sampled more often, the variability between locations becomes significant for the oxygen and hydrogen isotope composition. For all sampling events and the whole data set, nearly all of the variability is related to source of variance related to a particular group of wicks (e.g. within group variability).

Our results show that the isotope composition of snowmelt should be sampled using a relatively large number of wicks on site. In relatively homogeneous regions (e.g the same altitude, snow exposition and similar meteorological conditions) the variability among the different sampling sites is relatively small and makes only a small contribution to total variability.

Further work is needed to characterise the isotope composition of infiltrated melt water, particularly in karstic areas where snowmelt begins at different times, at different altitudes and it is often mixed with rain which blurs the snowmelt isotope signal in the runoff.

Acknowledgement. This study was financially supported by Slovenian Research Agency in the frame of basic research programmes (P1-0143, P1-0020), the EU Horizon 2020 project MASSTWIN (grant agreement No. 692241) and was part of IAEA CRP F3.20.06, the Slovenian subproject "Use of environmental isotopes in investigations of influence of snowmelt on stream runoff in the area of Julian Alps, NW Slovenia”. We thank all who helped, particularly S. Žigon, J. Herič, M. Grm, J. Hictaler, R. Rudolf, for their invaluable assistance with field sampling and laboratory work. We also acknowledge fruitful discussions with IAEA CRP partners during the meetings and thank the staff of the Isotope Hydrology Section at IAEA for assistance during the project, including providing the fiberglass rope (used for PCS experiment) and for the stable hydrogen analyses. Sincere thanks to David J. Heath for linguistic corrections.

\section{REFERENCES}

ARSO, 2017. Monthly bulletin Naše okolje. Ministry of the Environment and Spatial Planning, Slovenian Environment Agency [http://www.arso.gov.si/o\%20agenciji/knji\%C5\%BEnica/mese $\%$ C4\%8Dni\%20bilten/]. Accessed 11.6.2017.

Bavay, M., Grünewald, T., Lehning, M., 2013. Response of snow cover and runoff to climate change in high Alpine catchments of Eastern Switzerland. Advances in Water Resources, 55, 4-16.

Brenčič, M., Vreča, P., 2016. Hydrogeological and isotope mapping of the karstic River Savica in NW Slovenia. Environmental Earth Sciences, 75, 651.

Dansgaard, W., 1964. Stable isotopes in precipitation. Tellus, $16,436-468$.

DeWalle, D.R., Rango, A., 2008. Principles of Snow Hydrology. Cambridge University Press, Cambridge, 410 p.

Dolinar, M., Frantar, P., Kurnik, B., 2008. The characteristics of the water balance of Slovenia in the period 1971-2000. In: Proc. Mišičev vodarski dan 2008, pp. 19-25 (In Slovenian.)

Engel, M., Penna, D., Bertoldi G., Dell'Agnese, A., Soulsby, C., Comiti, F., 2016. Identifying run-off contributions during melt-induced run-off events in a glacierized alpine catchment. Hydrological Processes, 30, 343-364. 
Fayad, A., Simon Gascoin, S., Faour, G., López-Moreno, J.I., Drapeau, L., Le Page, M., Escadafal, R., 2017. Snow hydrology in Mediterranean mountain regions: A review. Journal of Hydrology, 551, 374-396.

Frantar, P., Nadbath, M., Ulaga, F., 2008. Water balance impact factors. In: Water Balance of Slovenia 1971-2000. Ministrstvo za okolje in prostor, Agencija za okolje, Ljubljana, pp. 15-27.

Friedman, I., Benson, C., Gleason, J., 1991. Isotopic changes during snow metamorphism. In: Taylor, H.P., O'Neil, J.R., Kaplan, I.R. (Eds.): Stable Isotope Geochemistry. A Tribute to Samuel Epstein. Special Publication no. 3. Geochemical Society, San Antonio, TX, USA, pp. 211-221.

Frisbee, M.D., Phillips, F.M., Campbell, A.R., Hendrickx, J.M.H., 2010. Modified passive capillary samplers for collecting samples of snowmelt infiltration for stable isotope analysis in remote, seasonally inaccessible watersheds 1: Laboratory evaluation. Hydrological Processes, 24, 825-833.

Hohenwallner, D., Saulnier, G., Castaings, W., Astengo, A., Brenčič, M., Bruno, C., Carolli, M., Chenut, J., De Bona, A., Doering, M., Dutto, E., Freundl, G., Harum, T., Holzeis, F., Jamsek, A., Klemenčič-Kosi, S., Kopeinig, C., Kozel, R., Klug, H., Lascours, S., Maiolini, B., Mignone, N., Neuwirth, J., Paccard, P., Pascariello, A., Pergher, P., Poltnig, W., Pušenjak, M., Rampazzo, R., Reszler, C., Robinson, C., Rollando, A., Rosso, M., Salvaro, M., Schlamberger, J., Scussel, R., Siligardi, M., Suette, G., Valentar, V., Varolo, E., Vecellio, C., Wagner, K., Zadravec, D., Zalavari, P., Zessar, H., Zolezzi, G., Brancelj, A., Bertoncelj, I., Brun, A., CadouxRivollet, M., Calvi, C., Defrancesco, C., Janetschek, H., Komma, J., Lachenal, P., Leskošek, T., Mezek, T., Mori, N., Mourembles, C., Rikanovic, R., 2011. Water Management in a Changing Environment. Strategies against Water Scarcity in the Alps. University of Savoie, Chambéry, 73 p.

Jeelani, G., Shah, R.A., Jacob, N., Deshpande, R.D., 2016. Estimation of snow and glacier melt contribution to Liddar stream in a mountainous catchment, western Himalaya: an isotopic approach. Isotopes in Environmental and Health Studies, 53, 18-35.

Jeelani, G., Shah, R.A., Deshpande, R.D., Fryar, A.E., Perrin, J., Mukherjee, A., 2017. Distinguishing and estimating recharge to karst springs in snow and glacier dominated mountainous basins of the western Himalaya, India. Journal of Hydrology, 550, 239-252.

Krajčí, P., Danko, M., Hlavčo, J., Kostka, Z., Holko, L., 2016. Experimental measurements for improved understanding and simulation of snowmelt events in the Western Tatra Mountains. Journal of Hydrology and Hydromechanics, 64, 316-328.

Lee, J., Feng, X., Faiia, A.M., Posmentier, E.S., Kirchner, J.W., Osterhuber, R., Taylor, S., 2010. Isotopic evolution of a seasonal snowcover and its melt by isotopic exchange between liquid water and ice. Chemical Geology, 270, 126-134.

Massone, H., Martinez, D., Vich, A., Londoño, M.Q., Trombotto, D., Grondona, S., 2016. Snowmelt contribution to the sustainability of the irrigated Mendoza's Oasis, Argentina: an isotope study. Environmental Earth Sciences, 75,520

Mankin, J.S., Viviroli, D., Singh, D., Hoekstra, A.Y., Diffenbaugh, N.S., 2015. The potential for snow to supply human water demand in the present and future. Environmental Research Letters, 10, 114016.

Moser, H., Stichler, W., 1974. Deuterium and oxygen-18 contents as an index of the properties of snow covers. International Association of Hydrological Sciences Publication, pp. 122-135.
N'da, A.B, Bouchaou, L., Reichert, B., Hanich, L., Ait Brahim, Y., Chehbouni, A., Beraaouz, E.H., Michelot, J.L., 2016. Isotopic signatures for the assessment of snow water resources in the Moroccan high Atlas mountains: contribution to surface and groundwater recharge. Environmental Earth Sciences, 75, 755.

Nadbath, M., 2012. Meteorološka postaja Zgornja Radovna. Naše okolje, Bilten Agencije RS za okolje, XIX, pp. 1-5.

Ogrinc, N., Kanduč, T., Stichler, W., Vreča, P., 2008. Spatial and seasonal variations in $\delta^{8} \mathrm{O}$ and $\delta \mathrm{D}$ values in the river Sava in Slovenia. Journal of Hydrology, 359, 303-312.

Ortar, J., Volk Bahun, M., Pavšek, M., Sinjur, I., Vertačnik, G., Brenčič, M., Polajnar, D., Sokratov, S.A., Vreča, P., 2013. Physical and isotopic chatacteristics of snowpack in NW Slovenia. International Snow Science Workshop Grenoble Chamonix Mont-Blanc, pp. 65-68.

Penna, D., Ahmad, M., Birks, S.J., Bouchaou, L., Brenčič, M., Butt, S., Holko, L., Jeelani, G., Martínez, D.E., Melikadze, G., Shanley, J.B., Sokratov, S.A., Stadnyk, T., Sugimoto, A., Vreča, P., 2014. A new method of snowmelt sampling for water stable isotopes. Hydrological Processes, 28, 5637-5644.

Penna, D., Zuecco, G., Crema, S., Trevisani, S., Cavalli, M., Pianezzola, L., Marchi, L., Borga, M., 2017. Response time and water origin in a steep nested catchment in the Italian Dolomites. Hydrological Processes, 31, 768-782.

Pomeroy, J.W., Brun, E., 2001. Physical properties of snow. In: Jones, H.G., Pomeroy, J.W., Walker, D.A., Hoham, R.W. (Eds.): Snow Ecology: An Interdisciplinary Examination of Snow-Covered Ecosystems. Cambridge University Press, Cambridge, UK, pp. 45-118.

Searle, S.R., Casella, G., Culloch, C.E., 2006. Variance Components. John Wiley \& Sons, $501 \mathrm{p}$.

Sokratov, S.A., Golubev, V.N., 2009. Snow isotopic content change by sublimation. Journal of Glaciology, 55, 823-828.

Torkar, A., 2016. Analysis of groundwater outflow through springs in fluvioglacial intergranular aquifers. $\mathrm{PhD}$ Thesis. University of Ljubljana, $135 \mathrm{p}$.

Torkar, A., Brenčič, M., Vreča, P., 2016. Chemical and isotopic characteristics of groundwater-dominated Radovna River (NW Slovenia). Environmental Earth Sciences, 75, 1296.

Viviroli, D., Weingartner, R., 2004. The hydrological significance of mountains: from regional to global scale. Hydrology and Earth System Sciences, 8, 1016-1029.

Viviroli, D., Archer, D.R., Buytaert, W., Fowler, H.J., Greenwood, G.B., Hamlet, A.F., Huang, Y., Koboltschnig, G., Litaor, M.I., López-Moreno, J.I., Lorentz, S., Schädler, B., Schreier, H., Schwaiger, K., Vuille, M., Woods, R., 2011. Climate change and mountain water resources: overview and recommendations for research, management and policy. Hydrology and Earth System Sciences, 15, 471-504.

Vreča, P., Brenčič, M., Sinjur, I., Vertačnik, G., Volk, M., Ortar, J., Torkar, A., Stibilj, V., Pavšek, M., 2013. The isotopic composition of precipitation and snow in the area of the Julian Alps and the Karavanke. In: Kuhar, M. (Eds.): Proc. 18. strokovno srečanje Slovenskega združenja za geodezijo in geofiziko Raziskave s področja geodezije in geofizike 2012. Fakulteta za gradbeništvo in geodezijo, Ljubljana, pp. 17-25. (In Slovenian.)

Weber, M., Bernhardt, M., Pomeroy, J.W., Fang, X., Härer, S., Schulz, K., 2016. Description of current and future snow processes in a small basin in the Bavarian Alps. Environmental Earth Sciences, 75, 1223.

Received 7 August 2017 Accepted 5 February 2018 